\title{
The In Vivo Transfer of Antigen-Induced Airway Reactions by Bronchial Lumen Cells
}

\author{
Roy Patterson, Irena M. Suszko, and Kathleen E. Harris, Section of \\ Allergy-Immunology, Department of Medicine, Northwestern University \\ Medical School, Chicago, Illinois 60611
}

A B S T RACT Rhesus monkeys with airway responses to aerosol challenge with Ascaris antigen constitute a primate model of inhalant asthma. Previous studies have shown that bronchial lavage cells from airway-reactive animals will release histamine or a slow-reactive substance of anaphylaxis after challenge with antigen.

Because these bronchial lumen cells are the first cells in contact with inhaled antigen, they may play a role in induction of antigen-induced airway responses. To evaluate this possibility, bronchial lumen lavage cells from animals with airway reactivity were transferred to the bronchial lumens of animals with negative airway responses to antigen challenge. The transfer of the bronchial lumen cells resulted in transient airway reactivity of the recipients to aerosol antigen challenge. It is suggested that the mast cells which constitute a component of the bronchial lumen cells may be the active cell alone, or in combination with other cells, which results in this primate immunoglobulin Emediated airway response and its transfer to nonreactive recipients.

\section{INTRODUCTION}

The experiments to be described resulted from the following series of observations. In studies of the cellular composition of bronchial lavage fluid, it was observed that a small percentage $(0.5-1 \%)$ of these cells had morphologic characteristics of mast cells, basophils, or both (1). Studies of these bronchial lumen mast cells $(B L M C)^{1}$ demonstrated that similar cells were present

\footnotetext{
Received for publication 9 January 1.978 and in revised form 6 April 1978.

${ }^{1}$ Abbreviations used in this paper: Asc., Ascaris; BF, breathing frequency; BLC, bronchial lumen cells; BLMC, bronchial lumen mast cells; $C$ dyn., dynamic compliance; E/I, expiratory-inspiratory time period; Hist., histamine dihydrochloride; $\mathrm{P}$, pressure; $\mathrm{PBS}$, phosphate-buffered saline; PERF, peak expiratory flow rate; PF, pulmonary function; PR, pulmonary resistance; $\mathrm{RC}$, respiratory cells; $\mathrm{TV}$, tidal volume.
}

in the bronchi of rhesus monkeys, dogs (1), and humans (2). The cells have been shown to be alive by their staining characteristics and ability to release histamine to immunologic stimuli $(1,3)$. When lavage cells are obtained from the bronchial lumens of rhesus monkeys with immunoglobulin E- (IgE-) mediated respiratory responses, the cells release histamine and a slow-reacting substance of anaphylaxis to appropriate antigenic stimuli (3). Although the mast cells could be identified with ease by routine microscopy, their exact classification was uncertain until appropriate electronmicroscopic studies were performed. These studies defined the bronchial lumen cells from humans as mast cells (4). The presence of living mast cells in the bronchi provides a source of respiratory mast cells for study which can be obtained by noninvasive techniques. A general question regarding bronchial lumen cells is whether, as free cells in the airway in first contact with inhaled antigen, they are capable of stimulating an antigen-induced airway response in the allergic animal. The answer to this question appeared to require the transfer of antigen-induced airway responses to a recipient animal with bronchial lumen cells of a reactive animal. In planning an experimental approach to achieve transfer, there appeared to be several complexities and potential problems. These included: $(a)$ the requirement of a sufficient number of bronchial lumen cells (BLC) from highly reactive donors, $(b)$ that these cells be distributed appropriately to the airway of recipient animals, and $(c)$ the use of an appropriate recipient animal. We have previously demonstrated that all rhesus monkeys with significant degrees of cutaneous reactivity to antigen do not have airway responses to aerosolized-antigen, and that animals with consistent airway reactivity to antigen have hyperreactive airways to analogues of acetylcholine similar to the human asthmatic (5). With these problems in mind, we developed test systems and report experiments which show that BLC from rhesus monkeys with airway reactivity to ascaris antigen will transfer this airway reactivity to recipient animals. The pos- 
sibility that the BLMC are the major cellular component that transfer airway reactivity cannot be proven, but deserves consideration and further study.

\section{METHODS}

Animals. Animals are young adult male and female Macaca mulatta which weigh from 2.5 to $11.5 \mathrm{~kg}$. Selection and screening of animals has been described in detail (5). All BLC donors with positive respiratory responses to aerosol challenge with ascaris antigen, had a positive response defined as previously reported (5).

Antigens and antisera. Ascaris antigen (Asc.) was obtained by sequential Sephadex (Pharmacia Fine Chemicals, Inc., Piscataway, N. J.) G-50 and G-75-column fractionation of Ascaris suum extract by the method of Hogarth-Scott (6). Standardization of each preparation of ASC. was by determination of protein as estimated by OD at $280 \mathrm{~nm}$ (Beckman DU spectrophotometer; Beckman Instruments, Inc., Fullerton, Calif.) and cutaneous titration in Asc.-sensitive animals (7). The preparation of Asc. in current use contains $0.8 \mathrm{mg}$ protein $\mathrm{N} / \mathrm{ml}$ and is stored at $-20^{\circ} \mathrm{C}$ in phosphate-buffered 0.15 $\mathrm{M} \mathrm{NaCl}, \mathrm{pH} 7.35$ (PBS).

Pharmacologic agents. Histamine dihydrochloride (Hist.) was obtained from Sigma Chemical Co., St. Louis, Mo.

Aerosol challenge and determination of pulmonary function $(P F)$ parameters. Animals received aerosol challenge no more frequently than every $2 \mathrm{wk}$. For an aerosol experiment, monkeys were anesthetized with pentobarbital; an endotracheal tube and an esophageal catheter were then inserted. After a period of observation, the animals received a control aerosol challenge with PBS. Base-line PF studies were obtained. Next, the aerosol challenge was delivered in a standard manner (8), with an in-line nebulizer in a Bird Mark VII (Bird Corp., Palm Springs, Calif.) respirator with all settings controlling respirations constant for each experiment in each animal. The animals received 15 inhalations of challenging antigen $(0.15 \mathrm{mg} \mathrm{N})$, and changes in PF subsequent to this challenge were recorded. The methodology for recording changes in PF has been described in detail (9). The following parameters of respiration were recorded: breathing frequency $(\mathrm{BF})$, peak expiratory flow rate (PEFR), expiratoryinspiratory time period $(\mathrm{E} / \mathrm{I})$, tidal volume $(\mathrm{TV})$, pulmonary resistance $(\mathrm{PR})$, and dynamic compliance (Cdyn.). The PEFR is the maximal expiratory flow during quiet (nonforced) expirations. An endotracheal tube was inserted into each animal, with the largest tube possible. The resistance of the tubes ranged from 4 to $6 \mathrm{~cm}_{2} \mathrm{O} /$ liters per s at 0.1 liters/s. The flow tracing was obtained by connecting the endotracheal tube to a Fleisch pneumotachograph (No. 00) (Dynasciences, Blue Bell, Pa.) and a Statham (PM5TC) transducer (Statham Instruments, Inc., Oxnard, Calif.). The BF, and PEFR were calculated from the flow tracing. The TV was obtained by electronic integration of the flow signal with time.

An open plastic catheter was inserted in the esophagus to the level of the nipple line and adjusted to minimize cardiac artifact. It was connected to one side of a Statham (PM5TC) transducer to determine changes in intrapleural pressure (P). The other side of the transducer was left open to atmosphere. The PR was determined by the method of Amdur and Mead (10) from simultaneous flow, $\mathrm{P}$, and TV signals. The $C$ dyn. is the ratio between $T V$ and the change in $P$ from the start to the end of inspiration (flow $=0$ ).

The computation of PR and C dyn. for each respiratory cycle was performed by an on-line analog computer (Respiratory Mechanics Computer; Buxco Electronics, Inc., Sharon, Conn.) which generates a signal proportional to the PR and C dyn.
The flow, $\mathrm{P}, \mathrm{TV}, \mathrm{PR}$, and $\mathrm{C}$ dyn. signals were recorded simultaneously on a Brush Mark 260 recorder (Gould, Inc., Systems Div., Cleveland, Ohio). All parameters were determined from this tracing by averaging 10 respiratory cycles.

Next, the absolute base-line PF values of the controls for each $\mathrm{PF}$ parameter were compared with the absolute values after PBS aerosol in animals either receiving BLC and or in animals not receiving BLC. The Student's $t$ test was used to evaluate these comparisons. The base-line PF values before antigen challenge were used to calculate the percent change from base line.

In a series of studies $(5,7,9,11)$, it has been established that although the absolute base-line PF levels varied between animals (9), these levels did not change significantly (more than $10 \%$ ) in an animal that had no aerosol challenge, or in any animal challenged by aerosol of PBS. Atropine did not result in more than that percentage of variation from the base line. Because of this, the most useful system for analysis of the respiratory response was found to be the comparison of post challenge results with each agonist and those obtained during the control period after the PBS challenge, with expression of the results as percent-change from the base line control period. The minimal criteria for positive responses of individual parameters are: $\mathrm{BF},+20 \%, \mathrm{E} / \mathrm{I},+25 \% ; \mathrm{PR},+25 \%$; TV, $-15 \%$; C dyn., $-20 \%$; and PEFR, $-25 \%$. These criteria represent mean $\pm 2 \mathrm{SD}$. Five of the six parameters must meet the above criteria to be considered a positive response.

Determination of Hist. aerosol threshold. The same monkeys used as recipients for respiratory cells (RC) were challenged by Hist. as an aerosol with concentrations of 6,60 , 600 , and $6,000 \mu \mathrm{g} / \mathrm{ml}$.

Cutaneous reactivity to Asc. Preparations of Asc. were tested in anesthetized monkeys that had received $5 \mathrm{ml}$ of 0.5\% Evans' Blue Dye (Warner-Lambert Pharmaceutical Co., Morris Plains, N. J.). Serial 10-fold dilutions of Asc. were used. Positive reactions were deep blue areas at least $10 \times 10$ $\mathrm{mm}$ in diameter and negative reactions had no bluing.

Bronchial lavage. For each transfer experiment, three monkeys reactive to Asc. (Table I) were anesthetized with intraperitoneal pentobarbital. $60 \mathrm{ml}$ of Ringer's-lactate solution was introduced into the tracheobronchial tree by means of a catheter inserted through an endotracheal tube. The Ringer's-lactate solution was aspirated and prepared for cell counts and transfer to recipient animals. Recovered bronchial lavage fluids from each of the three donor monkeys was centrifuged at $500 \mathrm{~g}$ for $10 \mathrm{~min}$ at $4^{\circ} \mathrm{C}$. The supernate was removed and $3 \mathrm{ml}$ of tissue culture medium (Medium 199 with Hanks' balanced salt solution, Grand Island Biological Co., Grand Island, N. Y.) was added to each cell pellet. The pellets were suspended and combined and the vol was brought to $10 \mathrm{ml}$. Cell counts were performed in a hemocytometer chamber. Cells were washed and centrifuged one more time at $500 \mathrm{~g}$ for $10 \mathrm{~min}$ at $4^{\circ} \mathrm{C}$. The supernate was decanted, $10 \mathrm{ml}$ of tissue culture medium was added and the donor cells resuspended to deliver to recipient.

Cell transfer experiments. Recipient monkeys were anesthetized with pentobarbital and donor cells were introduced through a catheter inserted through the endotracheal tube. Donor cells were suspended in $10 \mathrm{ml}$ of tissue culture medium. After injection of cells through the endotracheal tube, the recipient animals were vigorously rotated in an attempt to distribute cells into the bronchi. The animals immediately received a control aerosol challenge with PBS and 5 min later the Asc. challenge. Thus the Asc. challenge was given within $10 \mathrm{~min}$ of cell transfer.

Hist. release. $\mathrm{RC}$ obtained in lactated Ringer's solution were washed and resuspended in Tris buffer, $\mathrm{pH} 7.6$, which contained $\mathrm{Ca}++$ and $\mathrm{Mg}++$. To equal aliquots of cells, equal 
volumes of Tris buffer or a 1:100 dilution of Asc. in Tris buffer were added. This concentration of Asc. does not result in nonspecific Hist. release and has previously been used to demonstrate Hist. release from monkey cells (5). The Hist. was extracted from RC by standard methods (12) and content of Hist. was determined with a Bowman spectrophotofluorometer (American Instrument Co., Travenol Laboratories, Inc., Silver Spring, Md.).

\section{RESULTS}

Passive transfer of airway reactivity with $R C$. RC were obtained from monkeys with established airway responsiveness to Asc. antigen. The characteristics of these RC donors are shown in Table I. Immediately after transfer of RC to non-reactor animals the recipients were challenged by aerosol with PBS to determine if the $\mathrm{RC}$ were traumatized sufficiently during bronchial lavage and if transfer to recipients resulted in a nonspecific (nonimmunologic) airway response to a saline aerosol challenge. The absolute base-line values for PF parameters pre-PBS in all experiments $(n=12)$ were: $\mathrm{BF}, 24.5 \pm 5.0$ breaths $/ \mathrm{min}$; E/I, $1.09 \pm 0.2$; PR, $18.2 \pm 8.1$ $\mathrm{cm} \mathrm{H}_{2} \mathrm{O} /$ liter per s: $\mathrm{TV}, 39.7 \pm 14.2 \mathrm{ml} ; \mathrm{C}$ dyn. $33.4 \pm 19.6$ $\mathrm{ml} / \mathrm{cm} \mathrm{H}_{2} \mathrm{O}$; PEFR, $67.0 \pm 15.9 \mathrm{ml} / \mathrm{s}$. The absolute values after PBS aerosol in experiments where BLC were or were not delivered are shown in Table II. Statistical analysis by the Student's $t$ test showed no significant difference in any parameter. No nonspecific reactivity to PBS was transferred by RC. After PBS aerosol the

TABLE I

Characteristics of Donor and Recipient Rhesus Monkeys Used for Transfer of Antigen-Induced Reactivity of Airways of Rhesus Monkeys

\begin{tabular}{|c|c|c|c|c|c|}
\hline & $\begin{array}{c}\text { Animal } \\
\text { no. }\end{array}$ & $\begin{array}{l}\text { Cutaneous } \\
\text { reactivity }\end{array}$ & $\begin{array}{c}\text { Negative } \\
\text { airway } \\
\text { challenge }\end{array}$ & $\begin{array}{c}\text { Airway } \\
\text { response* }\end{array}$ & $\begin{array}{l}\text { Dura- } \\
\text { tion of } \\
\text { obser- } \\
\text { vation }\end{array}$ \\
\hline & & $\begin{array}{l}\text { serial 10-fold } \\
\text { dilution of Asc. } \\
\text { antigen }\end{array}$ & & & mo \\
\hline \multicolumn{6}{|l|}{ Donor } \\
\hline animals & 1 & 0.0001 & & $13 / 13$ & 19 \\
\hline & 2 & 0.001 & & $26 / 26$ & 41 \\
\hline & 3 & 0.00001 & & $34 / 34$ & 51 \\
\hline & 4 & 0.001 & & $14 / 14$ & 21 \\
\hline & 5 & 0.00001 & & $4 / 4$ & 8 \\
\hline \multicolumn{6}{|l|}{ Recipient } \\
\hline animals & 6 & 0.001 & $11 t$ & & 41 \\
\hline & 7 & 0.0001 & $11 t$ & & 52 \\
\hline & 8 & 0.1 & $12 \$$ & & 21 \\
\hline
\end{tabular}

* Number of positive responses/number of challenges.

\$ Two recipient animals initially had positive responses when first tested. Numbers record the sequential negative responses before the transfer experiments.

$\S$ This animal had no airway response to aerosol challenge at any time.
TABLE II

Absolute Values of Base-line PF and PF After PBS Aerosol Challenges in Animals Receiving BLMC or not Receiving BLMC

\begin{tabular}{llcc}
\hline & & \multicolumn{2}{c}{ PF after PBS } \\
\cline { 3 - 4 } \multicolumn{1}{c}{ PF } & Base-line PF & No cell transfer & Cell transfer \\
\hline BF, Breaths/min & $24.5 \pm 5.0^{*}$ & $22.0 \pm 1.7$ & $22.9 \pm 4.3$ \\
E/I & $1.09 \pm 0.2$ & $1.1 \pm 0.2$ & $1.0 \pm 0.1$ \\
PR, $\mathrm{cm} \mathrm{H}_{2} \mathrm{O} /$ liter/s & $18.2 \pm 8.1$ & $18.8 \pm 8.1$ & $15.8 \pm 5.8$ \\
TV, $\mathrm{ml}$ & $39.7 \pm 14.2$ & $40.7 \pm 12.0$ & $36.3 \pm 15.2$ \\
$\mathrm{C} \mathrm{dyn.,} \mathrm{ml} / \mathrm{cmH}_{2} \mathrm{O}$ & $33.4 \pm 19.6$ & $51.7 \pm 10.8$ & $25.6 \pm 18.1$ \\
PEFR, $\mathrm{ml} / \mathrm{s}$ & $67.0 \pm 15.9$ & $58.3 \pm 9.2$ & $60.9 \pm 19.9$
\end{tabular}

$*$ Mean \pm SD.

animals received the standard Asc. aerosol challenge. The results of Asc. aerosol challenges of recipient animals before and after RC transfer are shown in Fig. 1. These experiments were conducted at intervals of no less than 2 wk. After Asc. challenge in the pre-transfer animal (Fig. 1a), there was no significant variation in

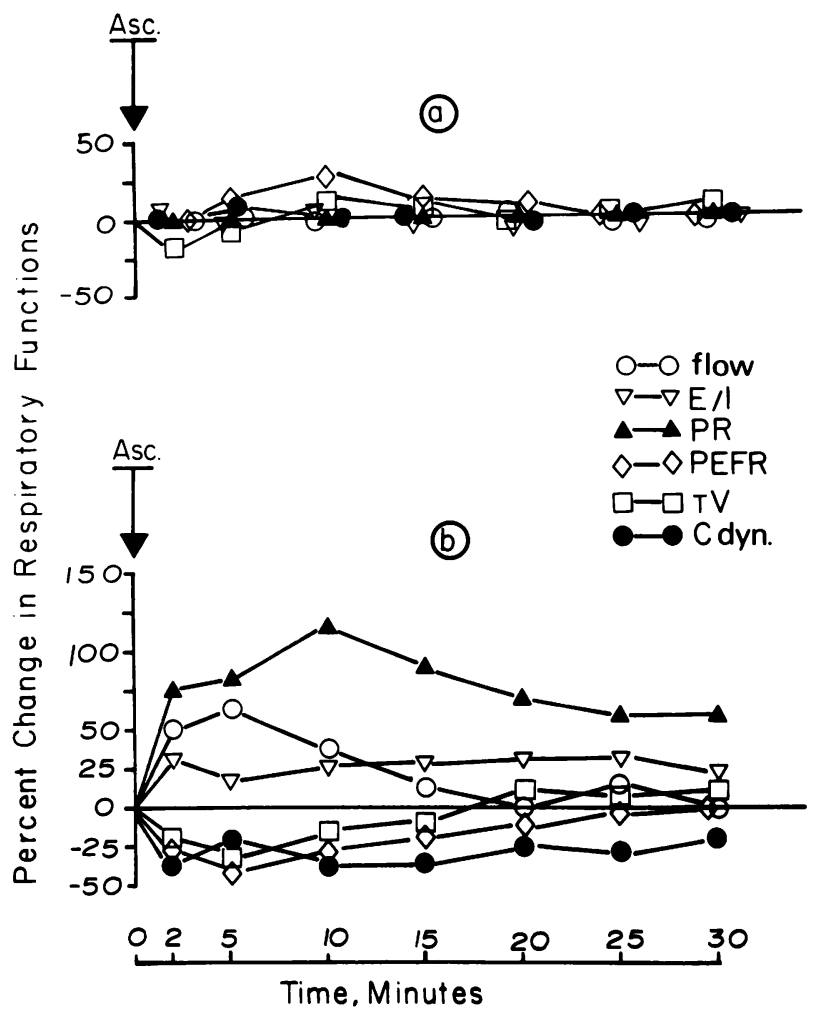

FIGURE 1 PF recordings of a recipient animal receiving Asc. aerosol challenges in separate experiments before and after BLC transfer to airways with bronchial cells from Asc.reactive cell donors (see Table I). PEFR $(\diamond-\diamond)$, PR $(\Delta-\Delta), C$ dyn. ( $-\Theta)$, TV $(\square-\square), E / I(\nabla-\nabla)$, $\mathrm{BF}(\mathrm{O}-\mathrm{O})$. (a) Asc. challenge before BLC transfer. (b). Asc. challenge after BLC transfer. 


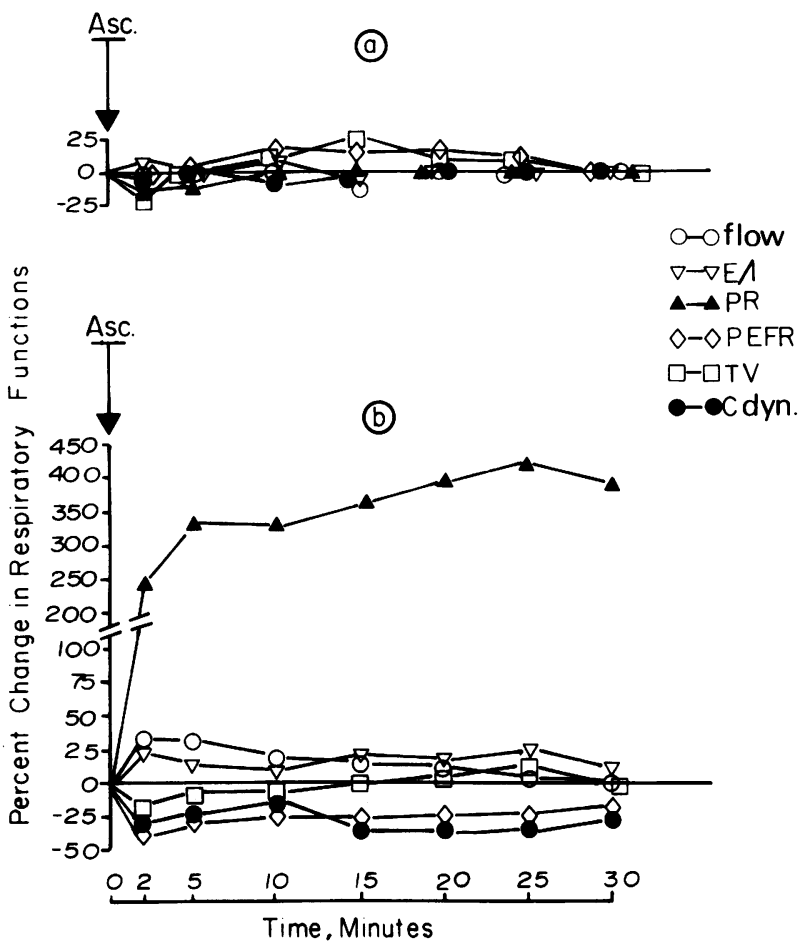

FIGURE 2 PF recordings of a recipient animal receiving Asc. aerosol challenges in separate experiments before and after BLC transfer to airways with bronchial cells from Asc.reactive cell donors (see Table I). PEFR $(\diamond-\diamond)$, PR $(\Delta-\Delta)$, C dyn. (O-O), TV ( $\square-\square), \mathrm{E} / \mathrm{I}(\nabla-\nabla)$, $\mathrm{BF}(\mathrm{O}-\mathrm{O})$. (a) Asc. challenge before BLC transfer. (b). Asc. challenge after BLC transfer.

the PF parameters. After Asc. challenge of the posttransfer recipient, there was an increase in BF, PR, and $\mathrm{E} / \mathrm{I}$; and a decrease in TV, PEFR, and C dyn. This response has been established in multiple experiments as characterizing the Asc.-induced airway response in the Asc.-sensitive monkey $(5,9,13)$. The direction of change of these PF parameters is consistent with the immunologically induced airway responses in this species. The magnitude of PF changes meets criteria for airway responses previously established.

The results of an experiment with a different monkey as an $\mathrm{RC}$ recipient are shown in Fig. 2. The control challenge with Asc. (pre-RC transfer) is negative (Fig. $2 a$ ), but after RC transfer aerosol challenge with Asc. is followed by a positive respiratory response (Fig. $2 b$ ). The results of these two experiments and four additional experiments are summarized in Table III. These results show positive-airway responses to Asc. challenge after RC transfer to the recipients in five of six experiments. One of these recipients had only a 0.1 titer by skin test to Asc. and had never had a positive airway response to Asc. The supernatant solutions from bronchial lavage cells were used for separate experiments. Cell supernates from three cell preparations which had successfully transferred bronchial reactivity were transferred to the bronchial lumens of non-Asc.reactive recipients. The recipient animals were then immediately challenged with Asc. in a manner identical to that after bronchial cell transfer. In three such experiments no respiratory responses occurred, which demonstrates that the cell supernate did not transfer reactivity under the conditions of the experiments. Although IgE antibody was likely present in the bronchial cell wash fluid, the short incubation interval (10 min) was not sufficient for passive cell sensitization.

BLC from nonreactive donors were transferred to the same nonreactive recipients used in initial, successful transfer experiments. The recipients of cells were then

TABLE III

Maximal Percent Changes in PF of Animals Which had Received BLMC and Asc. Challenge. BLMC Donors are Reactive to Aerosol Challenge with Asc. and BLMC Recipients are all Negative to Aerosol Challenge with Asc.

\begin{tabular}{|c|c|c|c|c|c|c|c|}
\hline \multirow{2}{*}{$\begin{array}{c}\text { Experiment } \\
\text { no. }\end{array}$} & \multirow{2}{*}{$\begin{array}{c}\text { Recipient } \\
\text { animals* }\end{array}$} & \multicolumn{6}{|c|}{ Maximal percent change } \\
\hline & & BF & PR & $\mathbf{E} / \mathbf{I}$ & C dyn. & PEFR & TV \\
\hline 1f & 7 & 62 & 62 & 33 & -29 & -35 & -28 \\
\hline $2 \ddagger$ & 6 & 33 & 411 & 26 & -34 & -33 & -15 \\
\hline 3 & 6 & 33 & 60 & 16 & -21 & -29 & -23 \\
\hline 4 & 6 & 123 & 0 & 61 & -45 & -38 & -33 \\
\hline 5 & 8 & 32 & 50 & 17 & -15 & -25 & -24 \\
\hline 6 & 6 & 0 & 16 & 16 & 12 & -25 & -14 \\
\hline Control§ & & $-4 \pm 10$ & $-5 \pm 13$ & $5 \pm 10$ & $18 \pm 20$ & $5 \pm 13$ & $6 \pm 7$ \\
\hline
\end{tabular}

* Animal nos. refer to cell recipients in Table I.

\$ PF curves of these animals are shown in Figs. 1 and 2.

$\$$ Maximal degree of variation in each Pulmonary Function parameter which may occur after aerosolized saline (see text) (mean $\pm \mathrm{SD})$. 
challenged with Asc. In four experiments there was no respiratory response. Thus, BLC from nonreactive donors do not transfer bronchial reactivity.

Cell counts, Hist. content of cells, and Hist. release. From Table IV, it can be seen that approximately $10^{8}$ RC will transfer respiratory responsiveness. From previous studies $(1,2), 0.5-1 \%$ of $\mathrm{RC}$ are of the mast cell type, so approximately $10^{6}$ donor mast cells were transferred to recipients. The results of these studies of BLMC which constitute about $1 \%$ of bronchial lavage cells (2) demonstrate there is about $3 \mu \mathrm{g}$ Hist./ $10^{6}$ mast cells. This confirms our previous study which reported a similar average amount of Hist./cell. The minimal number of RC required for transfer was not determined and would likely vary with both donor and recipient. Total Hist. content of cells transferred was approximately $3 \mu \mathrm{g}$ (Table IV). Hist. release from these RC, due to Asc. antigen, could be detected (Fig. 3) but was of minimal magnitude.

Aerosol Hist. thresholds of recipient animals. Rhesus monkeys used as recipients for BLC transfer (Table I and III) received aerosol challenges with increasing concentrations of Hist. $(6,60,600$, and 6,000 $\mu \mathrm{g} / \mathrm{ml})$. The concentration of Hist. that produces PF changes characteristic of the antigen-induced response (Figs. 1 and 2) was determined. These thresholds for monkeys 6,7 , and 8 (Tables I and III) were $6,000 \mu \mathrm{g} /$ $\mathrm{ml}$ for all three monkeys.

\section{DISCUSSION}

These results demonstrate $(a)$ that airway reactions to antigen can be transferred by RC obtained from bronchial lumens of donor animals with IgE-mediated airway responses and $(b)$ that cells within the bronchial lumen can initiate the airway response after immunologic stimulation. The latter observation may be of considerable significance because the mast cell, possibly

\section{TABLE IV}

Characteristics of BLC Containing BI MC used for Transfer of Airway Reactivity to Asc. to Nonreactive Recipients

\begin{tabular}{ccc}
\hline $\begin{array}{c}\text { Experiment } \\
\text { no.* }\end{array}$ & $\begin{array}{c}\text { Total number of cells } \\
\text { delivered to bronchi } \\
\text { of recipients }\end{array}$ & $\begin{array}{c}\text { Hist. in total number of cells } \\
\text { transferred }\end{array}$ \\
\hline
\end{tabular}

$\mu g$

$\begin{array}{rrr}1 & 12 \times 10^{7} & 2.8 \\ 2 & 16 \times 10^{7} & 7.0 \\ 3 & 10 \times 10^{7} & 3.4 \\ 4 & 6 \times 10^{7} & 2.0 \\ 5 & 7 \times 10^{7} & 3.4 \\ 6 & 6 \times 10^{7} & 2.2\end{array}$

* Experiments are the same as those recorded in Table III. $\$$ Combined cells obtained from bronchial lavage of three Asc. reactive donor animals (see Table I).

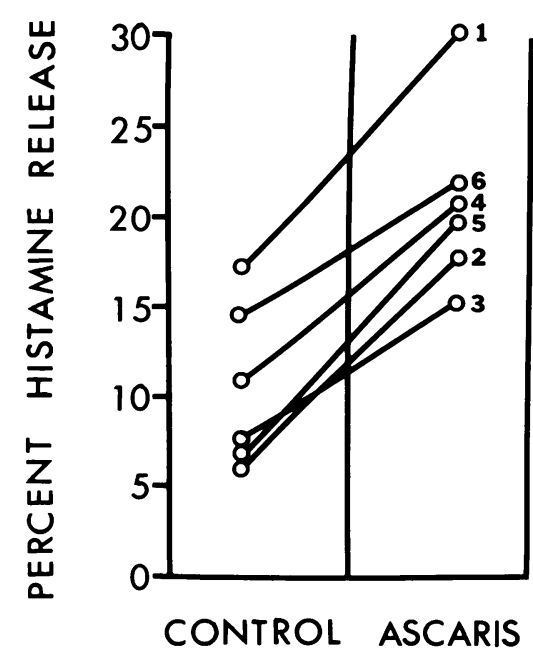

Figure 3 Percent Hist. release determined in vitro with aliquots of BLC used for transfer of airway reactivity from Asc.reactive to non Asc.-reactive monkeys. Cells were exposed to Tris buffer or Asc. antigen (1:100). Nos. refer to transfer experiments shown in Tables III and IV.

responsible, has been identified in three species: man, monkey, and dog. As the lumenal cells are the first cells exposed to inhaled antigenic materials, these cells can now be proposed as contributing to, or even playing a major role in, initiating IgE-mediated airway responses. This may be particularly true with high molecular weight antigens. For example, keyhole limpet hemocyanin, mol wt range 750,000 daltons in the dissociated form (14), produces an immediate-type response in allergic dogs (15). Antigens of such high mol wt would not be expected to penetrate to the submucosal mast cells rapidly enough to initiate an airway response within $2 \mathrm{~min}$, when such a response may occur. Such BLC may be a major contribution to the pathophysiologic mechanism in some types of human asthma. They may be the cells most affected by the use of inhaled cromolyn sodium and thus be of pharmacotherapeutic importance. Finally, their reactivity and release of vasoactive mediators may potentiate the penetration of inhaled antigens into deeper tissues of the respiratory tract.

The cells from the bronchial lumen used in these experiments which transfer reactivity have not been identified. It is possible or even probable that mast cells are involved. The Asc.-sensitive rhesus monkeys have reactivity consistent with IgE-mediated reactivity (16). Aerosolized anti-human IgE will produce an identical airway response as Asc. antigen (17). In monkeys, IgE fixes only to mast cells and basophils (18). This combination of indirect evidence indicates that mast cells may likely be major participants in the BLC which transfer the airway reactivity.

Comparison of the RC transfer studies which include 
the analysis of the total amount of Hist. in cells transferred (Table III) and the percent Hist. released (Fig. 3) with the threshold doses of Hist. required for an airway response in the same recipients are of interest. If all of the Hist. were released in vivo (which is most unlikely based on the in vitro studies shown in Fig. 3) only about $3 \mu \mathrm{g}$ would be released (Table III). The results of the threshold dose-response studies indicate that approximately a 1,000 -fold higher concentration of Hist. must be delivered to the airway of the same recipients to achieve an airway response of similar magnitude as that which results from antigen challenged recipient cells. Thus, if Hist. is significant in production of airway responses in this primate species, it must be as an added or synergistic mediator in conjunction with slow reactive substance of anaphalaxis, prostaglandin $F_{2 \alpha}$, other prostaglandin intermediates, other mediators, or promote the transmission of antigen to extralumenal mast cells of the recipient.

We conclude from these studies that respiratory lumen cells, which can transfer bronchial reactivity to unreactive animals, must now be considered as a major potential effector cell in IgE-mediated airway responses and possibly as participants in toxic, infectious, and non-IgE-mediated immunologic airway reactions in which mast cells may participate.

\section{ACKNOWLEDGMENTS}

This study was supported by U. S. Public Health Service grant AI 11759 and the Ernest S. Bazley grant.

\section{REFERENCES}

1. Patterson, R., Y. Tomita, S. H. Oh, I. M. Suszko, and J. J. Pruzansky. 1974. Respiratory mast cells and basophiloid cells. I. Evidence that they are secreted into the bronchial lumen, morphology, degranulation, and histamine release. Clin. Exp. Immunol. 16: 223-234.

2. Patterson, R., J. M. McKenna, I. M. Suszko, N. H. Solliday, J. J. Pruzansky, M. Roberts, and T. J. Kehoe. 1977. Living histamine-containing cells from the bronchial lumens of humans. Description and comparison of histamine content with cells of rhesus monkeys.J. Clin. Invest. 59: 217-225.

3. Patterson, R., L. W. Chakrin, I. M. Suszko, J. Mengel, and J. R. Wardell, Jr. 1976. IgE-mediated histamine and SRS-A release from respiratory cells and peripheral blood leu- kocyte of rhesus monkeys. J. Lab. Clin. Med. 87: 10161024.

4. Ts'ao, C., R. Patterson, J. M. McKenna, and I. M. Suszko. 1977. Ultra structural identification of mast cells obtained from human bronchial lumens. J. Allergy Clin. Immunol. 59: 320-326.

5. Patterson, R., K. E. Harris, I. M. Suszko, and M. Roberts. 1976. Reagin-mediated asthma in rhesus monkeys and relation to bronchial cell histamine release and airway reactivity to carbocholine. J. Clin. Invest. 57: 586-593.

6. Hogarth-Scott, R. S. 1967. The molecular weight range of nematode allergens. Immunology. 13: 535-537.

7. Patterson, R., and C. Talbot. 1969. Respiratory responses in subhuman primates with immediate-type hypersensitivity. J. Lab. Clin. Med. 73: 924-933.

8. Patterson, R., C. Talbot, and M. Brandfonbrener. 1971. The use of IgE mediated responses as a pharmacologic test system. The effect of disodium cromoglycate in respiratory and cutaneous reactions and on the electrocardiograms of rhesus monkeys. Int. Arch. Allergy Appl. Immunol. 41: 592-603.

9. Kelly, J. F., D. W. Cugell, R. Patterson, and K. E. Harris. 1974. Acute airway obstruction in rhesus monkeys induced by pharmacologic and immunologic stimuli. J. Lab. Clin. Med. 83: 738-749.

10. Amdur, M. O., and J. Mead. 1958. Mechanics of respiration in unanesthetized guinea pigs. Am. J. Physiol. 192: 364-368.

11. Miller, M. M., R. Patterson, and K. E. Harris. 1976. A comparison of immunologic asthma to two types of cholinergic respiratory responses in the rhesus monkey. J. Lab. Clin. Med. 88: 995-1007.

12. Pruzansky, J. J., and R. Patterson. 1966. Histamine release from leukocytes of hypersensitive individuals. I. Use of several antigens. J. Allergy. 38: 315-320.

13. Patterson, R., and J. F. Kelly. 1974. Animal models of the asthmatic state. Annu. Rev. Med. 25: 53-68.

14. Weigle, W. O. 1964. Immunochemical properties of hemocyanin. Immunochemistry. 1: 295-302.

15. Schatz, M., R. Patterson, H. M. Sommers, K. E. Harris, I. M. Suszko, and M. Roberts. 1977. Immediate-type hypersensitivity to keyhole limpet haemocyanin in the dog. Immunology. 32: 95-101.

16. Weiszer, I., R. Patterson, and J. J. Pruzansky. 1968. Ascaris hypersensitivity in the rhesus monkey. I. A model for the study of immediate type hypersensitivity in the primate. J. Allergy. 41: 14-22.

17. Patterson, R., and K. E. Harris. 1978. The qualitative evaluation of airway responses to immunologic and pharmacologic stimuli in rhesus monkeys. J. Allergy Clin. Immunol. 61: 261-267.

18. Tomioka, I., and K. Ishizaka. 1971. Mechanisms of passive sensitization. II. Presence of receptors for IgE on monkey mast cells. J. Immunol. 107: 971-978. 